\title{
Hubungan antara Proteinuria dan Hipoalbuminemia pada Anak dengan Sindrom Nefrotik yang Dirawat di RSUP Dr. M. Djamil Padang periode 2009-2012
}

\author{
Pratiwi Dian Pramana ${ }^{1}$, Mayetti $^{2}$, Husnil Kadri $^{3}$
}

\begin{abstract}
Abstrak
Sindrom nefrotik terdiri dari proteinuria massif, hipoalbuminemia, edema, serta dapat disertai hiperkolesterolemia. Proteinuria merupakan gejala utama pada sindrom nefrotik, sedangkan gejala klinis lainnya dianggap sebagai manifestasi sekunder. Kehilangan protein melalui urin menyebabkan terjadinya hipoalbuminemia. Penelitian ini bertujuan mengidentifikasi hubungan antara proteinuria dan hipoalbuminemia pada anak dengan sindrom nefrotik. Metode yang digunakan adalah studi retrospektif dengan desain Cross Sectional. Data sekunder diambil dari rekam medik pasien yang didiagnosis sebagai Sindrom Nefrotik Anak di Rumah Sakit Umum Pusat (RSUP) Dr. M. Djamil Padang Periode Januari 2009 - April 2012. Penelitian berlangsung dari Oktober 2011- Desember 2012. Hasil penelitian menunjukan insiden tertinggi sindrom nefrotik pada kelompok umur $>6$ tahun terutama pada anak laki-laki dengan rasio $1,43: 1$. Sebagian besar pasien memiliki kadar protein urin semikuantitatif +3 dengan rata-rata kadar protein urin kuantitatif $3,121 \pm 2,157 \mathrm{gr} / 24 \mathrm{jam}$. Hampir seluruh pasien mengalami hipoalbuminemia $(98,2 \%)$. Analisis statistik menunjukkan tidak terdapat hubungan yang bermakna antara proteinuria dan hipoalbuminemia $(p>0.05)$. Hal ini mungkin disebabkan oleh jumlah subjek yang kurang, sehingga penelitian selanjutnya diharapkan berlangsung lebih lama agar didapatkan jumlah subjek yang lebih besar.
\end{abstract}

Kata kunci: Anak dengan sindrom nefrotik, Proteinuria, Hipoalbuminemia

Abstract

Nephrotic syndrome consist of massive proteinuria, hypoalbuminemia, edema, and may be accompanied by hypercholesterolemia. Proteinuria is a major symptom of nephrotic syndrome, while the other clinical symptoms considered secondary manifestations. Loss of protein in the urine leads to hypoalbuminemia. This study aims to identify the relationship between proteinuria and hypoalbuminemia in children with Nephrotic Syndrome. Method of this research performed a retrospective study with cross sectional design. Secondary data were taken from medical record of patients that were diagnosed as Nephrotic Syndrome Children in General Hospital Dr. M. Djamil Padang period January 2009 - April 2012. The study was held on October 2011 - December 2012. The result of this study showed that the highest incidence of Nephrotic Syndrome in the age group >6 years old especially in male with the ratio 1,43:1. Most of patients have levels of semiquantitative urinary protein +3 with average levels of quantitative urinary protein $3.121 \pm 2.157 \mathrm{gr} / 24$ hours. Almost all of the patients had hypoalbuminemia (98.2\%). Statistical analysis showed that there was no significant relationship between proteinuria and hypoalbuminemia $(p>0.05)$. This may be due to the less number of subjects, so further research is expected to last much longer in order to have a larger number of subjects.

Keywords:Nephrotic syndrome children, Proteinuria, Hypoalbuminemia

Affiliasi penulis : ${ }^{1}$ Mahasiswa FK Unand, ${ }^{2}$ Bagian IKA FK Unand, ${ }^{3}$ Bagian Biokimia FK Unand.

Korespondensi : Fakultas Kedokteran Universitas Andalas Jl. Perintis Kemerdekaan No.94, Padang. Email: cikitiw_tiw@yahoo.com Telp: 085266391839

\section{Pendahuluan}

Sindrom Nefrotik (SN) adalah kumpulan gejala yang terdiri dari proteinuria massif $\left(\geq 40 \mathrm{mg} / \mathrm{m}^{2}\right.$ LPB/jam atau rasio protein/kreatinin pada urin sewaktu $>2$ atau dipstick $\geq 2+$ ), hipoalbuminemia $(\leq 2,5 \mathrm{gr} / \mathrm{dL})$, edema, serta dapat disertai hiperkolesterolemia (250 $\mathrm{mg} / \mathrm{uL}){ }^{1}$

Angka kejadian SN di Amerika dan Inggris berkisar antara 2-7 per 100.000 anak berusia di bawah 18 tahun per tahun, dengan perbandingan anak lakilaki dan perempuan 2:1. Di Departemen IImu Kesehatan Anak Fakultas Kedokteran Universitas Andalas (FKUI) / Rumah Sakit Cipto Mangunkusumo (RSCM) Jakarta, SN merupakan penyebab kunjungan sebagian besar pasien di Poliklinik Khusus Nefrologi dan merupakan penyebab tersering gagal ginjal anak yang dirawat antara tahun 1995-2000. Perbandingan SN pada anak laki-laki dan perempuan adalah 2:1.
Hasil penelitian retrospektif di bagian IKA Rumah Sakit Umum Pusat (RSUP) Dr. M. Djamil periode 19972000, mendapatkan bahwa perbandingan kejadian sindrom nefrotik antara anak laki-laki dan perempuan $1,7: 1$. $^{1,2}$

Penelitian cross-sectional prospektif telah dilakukan pada 44 anak dengan Sindrom Nefrotik Idiopatik (SNI) dari September 2000-2007 di rumah sakit Shahrivar Iran (dengan usia saat onset sampai 14 tahun). Ada 29 anak laki-laki (66\%) dan 15 anak perempuan $(34 \%)(L: P=1,9 / 1)$. Usia rata-rata saat onset SNI adalah 4,87 $\pm 3,24$ tahun (usia onset sampai 14 tahun). Salah satu pasien merupakan pasien SN bawaan. Rata-rata albumin serum $1,75 \pm 0,45 \mathrm{gr} / \mathrm{dL}$, ekskresi protein 24 jam 3344,84 $\pm 2344,38 \mathrm{mg}$.

Hipoalbuminemia merupakan gejala yang penting dalam menegakkan diagnosis sindrom nefrotik, yaitu apabila konsentrasi albumin plasma $\leq$ 2,5 g/dL. Semakin rendah kadar albumin dalam plasma semakin berat manifestasi klinis yang timbul pada anak dengan $\mathrm{SN}{ }^{4}$

Kehilangan protein melalui urin menyebabkan terjadinya hipoalbuminemia. Meskipun demikian, faktor lain juga dapat menyebabkan hipoalbuminemia, 
diantaranya adalah penurunan sintesis, peningkatan katabolisme, serta peningkatan kehilangan melalui saluran cerna. $5,6,7$

Dalam keadaan seimbang, laju sintesis albumin, degradasi dan pengeluaran dari tubuh adalah seimbang. Pada anak dengan SN terdapat hubungan terbalik antara laju ekskresi protein urin dan derajat hipoalbuminemia. Namun keadaan ini tidak merupakan korelasi yang ketat, terutama pada anak dengan proteinuria yang menetap lama dan tidak responsif steroid, albumin serumnya dapat kembali normal atau hampir normal dengan atau tanpa perubahan pada laju ekskresi protein. Laju sintesis albumin pada SN dalam keadaan seimbang ternyata tidak menurun, bahkan meningkat atau normal. Pada suatu penelitian terhadap anak ditemukan kenaikan laju sintesis dua kali pada SN (dan anak dengan hipoalbuminemia dengan penyebab non hepatik lainnya) menunjukkan bahwa kapasitas peningkatan sintesis hati terhadap albumin tidak cukup untuk mengkompensasi laju kehilangan albumin yang abnormal.

Penelitian ini bertujuan untuk mengetahui hubungan antara proteinuria dan hipoalbuminemia pada anak dengan SN yang dirawat di RSUP Dr. M. Djamil Padang.

\section{Metode}

Penelitian dilakukan di Instalasi Rekam Medis RSUP Dr. M. Djamil Padang pada bulan Oktober 2011 - Desember 2012.Subjek dalam penelitian ini sebanyak 56 orang. Data penelitian adalah rekam medik semua anak yang telah didiagnosis oleh dokter spesialis anak sebagai penderita SN yang dirawat di Instalasi Rawat Inap RSUP Dr. M. Djamil Padang periode 1 Januari 2009 - 30 April 2012 yang memenuhi kriteria inklusi dan tidak terdapat kriteria eksklusi. Data yang diperoleh diolah dengan software computer yaitu SPSS, dan untuk analisis hasil penelitiannya digunakan uji korelasi Pearson dengan tingkat pemaknaan $p<0,05$.

\section{Hasil dan Pembahasan}

a. Karakteristik Pasien

Tabel 1: Distribusi frekuensi subjek penelitian berdasarkan umur

\begin{tabular}{ccc}
\hline $\begin{array}{c}\text { Kelompok } \\
\text { Umur (tahun) }\end{array}$ & Frekuensi & $\begin{array}{c}\text { Persentase } \\
(\%)\end{array}$ \\
\hline $1-<2$ & 3 & 5,4 \\
$2-6$ & 22 & 39,3 \\
$>6$ & 31 & 55,4 \\
& & \\
\hline Total & $\mathbf{5 6}$ & $\mathbf{1 0 0}$ \\
\hline
\end{tabular}

Pada tabel di atas dapat dilihat bahwa kelompok umur tertinggi pada anak dengan $\mathrm{SN}$ adalah $>6$ tahun sebanyak 31 orang $(55,4 \%)$ dan terendah pada kelompok umur $1-<2$ tahun sebanyak 3 orang $(5,4 \%)$. Hal ini tidak jauh berbeda dengan penelitian yang dilakukan oleh Nasution dan Aumas (2001) periode 1997-2000 di bagian IKA RSUP Dr. M. Djamil Padang yang menemukan penderita sindrom nefrotik anak tertinggi usia 5-12 tahun. ${ }^{2}$

Pada penelitian ini didapatkan umur anak dengan sindrom nefrotik bervariasi dari yang terendah adalah 1 tahun dan tertinggi adalah 14 tahun. Ratarata umur anak dengan SN adalah 6,98 $\pm 3,91$ tahun.
Hal ini tidak jauh berbeda dengan hasil yang didapatkan oleh Garniasih dkk (2008) di Bagian IImu Kesehatan Anak (IKA) RS dr. Hasan Sadikin Bandung mulai bulan Juli - September 2007 bahwa usia ratarata anak dengan sindrom nefrotik adalah $6,80 \pm 3,39$ tahun. ${ }^{8}$

Tabel 2: Distribusi frekuensi subjek penelitian berdasarkan jenis kelamin

\begin{tabular}{ccc}
\hline $\begin{array}{c}\text { Jenis } \\
\text { Kelamin }\end{array}$ & Frekuensi & $\begin{array}{c}\text { Persentase } \\
(\%)\end{array}$ \\
\hline Laki-laki & 33 & 58,9 \\
Perempuan & 23 & 41,1 \\
\hline Total & $\mathbf{5 6}$ & $\mathbf{1 0 0}$ \\
\hline
\end{tabular}

Pada tabel di atas dapat dilihat bahwa anak dengan SN laki-laki lebih banyak daripada anak perempuan. Rasio kejadian SN pada anak laki-laki dengan perempuan sebesar 1,43:1. Khairani (2007) mendapatkan hasil yang hampir sama pada penelitian yang dilakukannya di RSUP Dr. M. Djamil Padang periode 2001-2006 yaitu kejadian SN lebih banyak terjadi pada anak laki-laki dengan rasio antara laki-laki dan perempuan adalah 1,42:1.

b. Kadar Protein Urin

Tabel 3: Distribusi frekuensi subjek berdasarkan kadar protein urin

\begin{tabular}{ccc}
\hline $\begin{array}{c}\text { Proteinuria } \\
\text { (semikuantitatif) }\end{array}$ & Frekuensi & $\begin{array}{c}\text { Persentase } \\
(\%)\end{array}$ \\
\hline+1 & 2 & 3,6 \\
+2 & 14 & 25,0 \\
+3 & 40 & 71,4 \\
\hline Total & 56 & $\mathbf{1 0 0}$ \\
\hline
\end{tabular}

Pada tabel di atas dapat diihat bahwa kadar protein urin (semikuantitatif) terbanyak pada anak dengan SN adalah +3 sebanyak 40 orang $(71,4 \%)$. Keadaan ini sama dengan yang didapatkan oleh Handayani (2007) di RS Dr. Wahidin Sudirohusodo, Makassar, yaitu kadar protein urin semikuantitatif pada sindrom nefrotik terbanyak adalah +3 . $^{10}$

Data rekam medik 56 anak dengan SN didapatkan hanya 20 anak yang diperiksa kadar protein urin secara kuantitatif (tes Esbach). Hasil analisis didapatkan kadar protein urin terendah pada anak adalah $0,5 \mathrm{gr} / 24$ jam sedangkan kadar protein urin tertinggi adalah 7,5 gr/24 jam. Rata-rata kadar protein urin anak dengan SN adalah 3,121 $\pm 2,157$ gr/24 jam.

c. Kadar Albumin Serum

Tabel 4: Distribusi frekuensi subjek penelitian berdasarkan kadar albumin serum

\begin{tabular}{ccc}
\hline $\begin{array}{c}\text { Kadar Albumin } \\
\text { Serum }\end{array}$ & Frekuensi & $\begin{array}{c}\text { Persentase } \\
(\%)\end{array}$ \\
\hline Hipoalbuminemia & 55 & 98,2 \\
Normoalbuminemia & 1 & 1,8 \\
\hline Total & 56 & $\mathbf{1 0 0}$ \\
\hline
\end{tabular}

Pada tabel di atas dapat dilihat bahwa hampir seluruh anak dengan SN mengalami hipoalbuminemia $(98,2 \%)$ dan hanya terdapat 1 anak dengan 
normoalbuminemia. Hal ini sesuai dengan yang ditulis oleh Wirya (2002) bahwa albumin serum dapat kembali normal atau hampir normal terutama pada anak dengan proteinuria yang menetap lama dan tidak responsif steroid. $^{1}$

\section{d. Hubungan Proteinuria dengan Hipoalbuminemia}

Uji analisis bivariat hanya dilakukan pada 55 anak yang mengalami hipoalbuminemia.

Tabel 5: Hasil analisis hubungan proteinuria (semikuantitatif) dengan hipoalbuminemia pada anak dengan SN

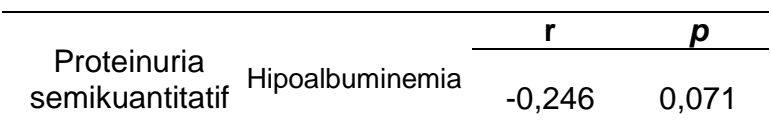

Pada tabel di atas dapat dilihat bahwa penelitian ini mendapatkan nilai koefisien korelasi Spearman ( $r$ ) sebesar -0,246, yang menunjukkan derajat hubungan yang sangat lemah dan.

Tabel 6: Hasil analisis hubungan proteinuria (kuantitatif) dengan hipoalbuminemia pada anak dengan SN

\begin{tabular}{llcc}
\hline \multirow{2}{*}{$\begin{array}{l}\text { Proteinuria } \\
\text { (kuantitatif) }\end{array}$} & Hipoalbuminemia & $\mathbf{R}$ & $\boldsymbol{P}$ \\
\cline { 3 - 3 } & & $+0,267$ & 0,255 \\
\hline
\end{tabular}

Pada tabel di atas dapat dilihat bahwa penelitian ini mendapatkan nilai koefisien korelasi Spearman ( $r$ ) sebesar $+0,267$, yang menunjukkan derajat hubungan yang sangat lemah dan tarif signifikansi (p) 0,255 ( $p>0,05)$.

Pada penelitian ini, dari hasil analisis statistik memakai uji korelasi Spearman antara proteinuria dan hipoalbuminemia didapatkan derajat hubungan yang sangat lemah dengan nilai koefisien korelasi Spearman (r) adalah -0,246 dan $+0,267$. Tarif signifikansi $(p)$ pada penelitian ini adalah 0,071 dan 0,255 yang berarti $p>0,05$. Berdasarkan hasil tersebut, hipotesis penelitian ini yang menyatakan "Terdapat hubungan antara proteinuria dan hipoalbuminemia pada anak dengan sindrom nefrotik" ditolak dan tidak memiliki hubungan yang bermakna.

Hasil penelitian ini tidak sesuai dengan kepustakaan yang menyebutkan bahwa pada sindrom nefrotik, hipoalbuminemia disebabkan oleh proteinuria massif. Pada anak dengan SN terdapat hubungan terbalik antara laju ekskresi protein urin dan derajat hipoalbuminemia. Menurut Rodrigo dkk (1996) menyebutkan bahwa semakin tinggi tingkat keparahan proteinuria, semakin rendah konsentrasi albumin darah. ${ }^{11}$ Pada penelitian ini, tidak adanya hubungan yang bermakna antara proteinuria dan hipoalbuminemia tersebut, mungkin disebabkan oleh karena kadar albumin darah ditentukan oleh masukan dari sintesis hepar dan pengeluaran akibat degradasi metabolik, ekskresi renal, dan gastrointestinal. Jadi, proteinuria pada SN tidak hanya ditentukan oleh ekskresi renal. ${ }^{5}$

Sintesis albumin mengalami penurunan yang relatif dini pada keadaan malnutrisi protein, seperti kwashiorkor. $^{12}$ Laju sintesis albumin hepar juga dipengaruhi oleh masukan protein dan energi. Pemasukan protein dapat berkurang apabila terjadi gangguan pada saluran cerna yang menyebabkan nafsu makan menurun dan mual-mual. Kehilangan sejumlah protein dari tubuh melalui usus (protein losing enteropathy) juga dapat menyebabkan keadaan hipoalbuminemia. $^{1}$

Pada penelitian ini faktor-faktor yang mempengaruhi hipoalbuminemia tersebut tidak dapat disingkirkan sebagai faktor perancu penelitian seperti; intake protein dan status gizi pasien. Begitu juga dengan sejumlah penyakit saluran cerna yang mengakibatkan kehilangan protein melalui usus.

\section{Kesimpulan}

Berdasarkan penelitian yang telah dilakukan, dapat disimpulkan bahwa :

1. Rata-rata umur anak dengan sindrom nefrotik adalah 6,98 tahun. Paling banyak terjadi pada kelompok umur $>6$ tahun.

2. Lebih dari setengah anak dengan sindrom nefrotik adalah laki-laki dengan rasio laki-laki dan perempuan sebesar 1,43:1.

3. Kadar protein urin semikuantitatif terbanyak pada anak dengan sindrom nefrotik adalah +3 . Ratarata kadar protein urin kuantitatif anak adalah 3,121 gr/24 jam.

4. Hampir seluruh anak dengan sindrom nefrotik mengalami hipoalbuminemia dan hanya terdapat 1 anak dengan normoalbuminemia.

5. Tidak terdapat hubungan yang bermakna antara proteinuria dan hipoalbuminemia pada anak dengan sindrom nefrotik.

\section{Daftar Pustaka :}

1. Wirya WIGN. Sindrom nefrotik. Dalam: Alatas $\mathrm{H}$, Tambunan $\mathrm{T}$, Trihono PP, (penyunting). Buku ajar nefrologi anak jilid 2. Jakarta: Balai Penerbit FKUI; 2002. hlm. 382-419.

2. Nasution A, Aumas P. Gambaran klinis laboratorium dan hasil pengobatan sindrom nefrotik pada anak yang dirawat di bagian IKA RSUP Dr. M. Djamil Padang periode 19972000. Disampaikan pada KONIKA XII Bali: Ikatan Dokter Anak Indonesia; 2001.

3. Safaei A, Maleknejad S. Spectrum of childhood nephrotic syndrome in Iran: a single center study. Indian Journal of Nephrology. 2009; 19(3): 87-90.

4. Webb, Nicholas JA, Postlethwaite RJ. Clinical pediatric nephrology. New York: Oxford University Press; 2003.

5. Alpers A. Sindrom nefrotik. Dalam (terjemahan) Rudolph AM, Hoffman JI, Rudolph CD, (penyunting). Buku ajar pediatri Rudolph. Edisi ke-20. Jakarta: EGC; 2006. hlm. 1503-8.

6. Hull D, Johnston DI. Dasar-dasar pediatri. Edisi ke-3 (terjemahan). Jakarta: EGC; 2008.

7. Nelson WE, Behrman RE, Kliegman RM, Arvin Ann M. Ilmu kesehatan anak Nelson. Vol.3; editor edisi bahasa Indonesia, A. Samik Wahab. Edisi ke- 15. Jakarta: EGC; 2000.

8. Garniasih D, Djais ST, Garna H. Hubungan antara kadar albumin dan kalsium serum pada sindrom nefrotik anak. Sari Pediatri. 2008; 10(2): 100-5.

9. Khairani Y. Hubungan hipoalbuminemia dengan hiperkolesterolemia pada pasien sindrom nefrotik anak di RSUP dr. M. Djamil Padang periode 2001-2006. (skripsi). Universitas Andalas Padang. 2007. 
10. Handayani I, Rusli B, Hardjoeno. Gambaran kadar kolesterol, albumin dan sedimen urin penderita anak sindrom nefrotik. Indonesian Jurnal of Clinical Pathology and Medical Laboratory. 2007; 13(2): 49-52.

11. Rodrigo R, Bravo I, Pino M, 1996. Proteinuria and albumin homeostasis in the nephrotic syndrome: effect of dietary protein intake. Nutrition Reviews. 1996; 54(11): 337-47.
12. Murray RK, Granner DK, Rodwell VW. Biokimia Harper. Edisi ke-27. alih bahasa, Brahm A. Pendit; editor edisi Bahasa Indonesia, Nanda Wulandari dkk. Jakarta: EGC; 2009.

13. Sukandar E. Nefrologi klinik. Edisi Ke-3. Pusat Informasi IImiah (PII) Bagian IImu Penyakit Dalam FK UNPAD/RS Dr. Hasan Sadikin Bandung. 2006. 